\title{
The Heritage Protection Bill: its effect on the current
} systems

\author{
by Nigel Hewitson
}

$\mathrm{T}$ he way the historic built environment is protected in this country has developed piecemeal over the years with separate statutory systems to protect different elements of it. The draft Heritage Protection Bill, published for pre-legislative scrutiny on April 2, 2008 proposes major changes to the current systems. This paper examines the current systems in turn and concludes with a look at the main changes proposed in the Heritage Protection Bill.

\section{SCHEDULED MONUMENTS}

Protection of the historic built environment began with the passage of the Ancient Monuments Protection Act 1882. This Act provided for protection for a list of 69 specified monuments and "other monuments of a like character of which the Commissioners [of Works] may consent to become the guardian".

The protection system was consolidated and amended by the Ancient Monuments and Archaeological Areas Act 1979, which replaced "preservation orders" with the current system of scheduling leading to a requirement for scheduled monument consent. Section 1 of the Act provides for the Secretary of State to compile and maintain a schedule of monuments "of national importance".

"Monument" is defined in section 61 as:

"(a) Any building, structure or work whether above or below the surface of the land and any cave or excavation,

(b) Any site comprising the remains of any such building, structure or work or of any cave or excavation, and

(c) Any site comprising or comprising the remains of any vehicle, vessel or aircraft or other moveable structure or part thereof which neither constitutes or forms part of any work which is a monument within paragraph (a) above”.

The Schedule contained some 19,750 entries as at 2005.

Once a monument as defined is included in the Schedule it is an offence under section 2 without scheduled monument consent to carry out: "any works resulting in the demolition or destruction of or any damage to a scheduled monument, any works for the purpose of moving or repairing a scheduled monument or any part of it or making any alterations to additions thereto or any flooding or tipping operation".

Scheduled monument consent is obtained from the Secretary of State for Culture Media and Sport. There is no formal right to appeal against refusal of scheduled monument consent but if the Secretary of State is minded to refuse an application the applicant is afforded an opportunity to appear before a public inquiry before a decision is made.

Scheduling is really aimed at preserving unoccupied structures, but until the introduction of the system of listed buildings (see below) in 1948, it was the only means of statutorily protecting historic buildings. This led to a number of buildings in use, notably a number of the livery halls in London, being scheduled. Many of them were subsequently also listed, but scheduling takes precedence over listing and therefore changes and adaptations to the buildings require scheduled monument consent.

\section{LISTED BUILDINGS}

The concept of listing a building was introduced by the Town and Country Planning Act 1947, which came into force on July 1, 1948. The current legislative provisions are contained in the Planning (Listed Buildings and Conservation Areas) Act 1990 ("the 1990 Act”). Whereas the ancient monuments legislation was designed to apply to unoccupied buildings and structures which it was perceived ought properly to be preserved intact, the listing system provides for some flexibility. Most planning authorities recognise that the best way to ensure that a listed building will be properly maintained and preserved is to ensure that it has a viable use. This often entails a compromise and allowing limited adaptations to enable a use to continue and thrive.

The 1990 Act provides for the Secretary of State to compile a list of buildings of special architectural or 
historic interest. A "building" is given the same meaning as in the Town and Country Planning Act 1990 and so it includes a structure or erection, although neither of these latter terms is defined. In practice a wide variety of things can be covered by listing including statues, gravestones, lamp posts and telephone boxes. The phrase "special architectural or historic interest" is not defined in the Act but some guidance can be found in Planning Policy Guidance Note 15 at paragraph 6.10 , which categorises the principal factors as follows:

"Architectural interest: the lists are meant to include all buildings which are of importance to the nation for the interest of their architectural design, decorations and craftsmanship; also important examples of particular building types and techniques (e.g. buildings displaying technological innovation or virtuosity) and significant plan forms;

Historic interest: this includes buildings which illustrate important aspects of the nation's social, economic, cultural or military history;

Close historical association with nationally important people or events;

Group value, especially where buildings comprise an important architectural or historical unity or a fine example of planning (e.g. squares, terraces or model villages).”

There are currently some 370,000 entries on the list, probably representing 500,000 buildings.

Section 1(5) of the 1990 Act provides that:

"In this Act, "Listed Building" means a building which is for the time being included in a list compiled or approved by the Secretary of State under this section; and for the purposes of this Act

(a) any object or structure fixed to the building; and

(b) any object or structure within the curtilage of the building which, although not fixed to the building, forms part of the land and has done so since before 1 July 1948

shall be treated as part of the building."

Making judgments on what is listed with the building is, in practice, complex, with different tests to be applied to different types of object or structure which might fall to be considered to be part of the listing. In summary, the following are covered by listing:

1. the building included in the list itself ("the principal building") including its interior;

2. any object fixed to the principal building provided that it is a "fixture" according to the normal rules of land law (degree of annexation and purpose of annexation);

3. any structure fixed to the principal building provided that it is "ancillary" to the principal building;

4. any building in existence on July 1, 1948 in the curtilage of the principal building (relevant matters being the physical layout of the principal building and any other buildings thought to be in the curtilage, their ownership past and present and their function past and present).

Once a building is listed it is a criminal offence to carry out any works either for its demolition (which, following the case of Shimizu (UK) Limited v Westminster City Council, means complete demolition - partial demolition being considered to be a form of alteration) or any works for its alteration or extension in any manner which affects its character as a building of special architectural or historic interest unless listed building consent is first obtained.

Listing building consent is obtained from the local planning authority and may be subject to conditions. Appeals against refusal of listed building consent or failure to determine an application within the statutory period lies to the Secretary of State, who may also call in applications for her own determination. In addition to prosecuting for carrying out works without listed building consent, the local planning authority has the power to issue a listed building enforcement notice requiring the building to be restored to its former state or, if that is not possible, for works to be carried out to remedy the harm done. There is no time limit on the issue of such a notice, so it is very much a case of "buyer beware".

\section{CONSERVATION AREAS}

The Civic Amenities Act 1967 introduced the idea of protecting areas as opposed to individual buildings. The relevant provisions (now contained in Part II of the 1990 Act) allow a local authority to designate as a conservation area "an area of special architectural or historic interest the character or appearance of which it is desirable to preserve or enhance". By 2005 there were almost 10,000 conservation areas in England and Wales. Although no one knows how many buildings this represents, it seems likely that there are considerably more buildings in conservation areas than there are buildings listed in their own right.

The consequences of designation are principally the following:

1. The local planning authority is under a general duty, in carrying out its planning functions, to pay special attention to the desirability of the preservation or enhancement of the character or appearance of the conservation area.

2. Conservation area consent is required for demolition of an unlisted building in a conservation area.

3. Some permitted development rights are reduced or removed altogether by virtue of designation of a conservation area and it is possible to make an Article 4 direction completely removing permitted development rights or any of them. 
4. There is limited protection for trees in conservation areas in that six weeks notice of any works to a tree in a conservation area has to be given to the local planning authority which may then make a tree preservation order in relation to that tree.

\section{Non-statutory protections}

English Heritage maintains two non-statutory registers: one of historic parks and gardens and the other of historic battlefields. Neither of these has any statutory force and no separate control systems flow from inclusion of land on either register. The fact of inclusion in the register, however, is a material consideration when considering any planning application on such land or affecting its setting.

World Heritage Sites are "inscribed" by the World Heritage Committee of the International Committee on Monuments and Sites ("ICOMOS"). World Heritage Sites are defined as "parts of the cultural or natural heritage [that] are of outstanding interest and therefore need to be preserved as part of the world heritage of mankind as a whole". There are currently 27 such sites, both natural and "works of man" in the UK and its dependant territories. The UK Government is under a treaty obligation to provide for "the identification, protection, presentation and rehabilitation" of World Heritage Sites. This includes an "effective system of collective protection". At present there is no separate system for protecting World Heritage Sites as such, although most, if not all, such sites are, in fact, protected by other statutory regimes.

\section{THE PROPOSED REFORMS}

The piecemeal development of protection for different elements of the historic environment over a period of time has led to a fragmented system. It is against this background that the Government began what became known as the "Heritage Protection Review", which culminated in the publication of the draft Heritage Protection Bill in April 2008.

The "big idea", if I can put it that way, of the Heritage Protection Review was to have a single register of all the historic assets warranting protection, with a detailed explanation of what is important about them and why they merit protection, and a map showing the exact extent of the designation (thus obviating concerns about the extent of listing). In the event, what the Bill proposes falls somewhat short of that. The Bill proposes a "Heritage Register for England" and a "Heritage Register for Wales" ("the Registers"). The Registers would include:

- "heritage structures" comprising historic buildings and archaeological sites including existing listed buildings and scheduled monuments and expanded to cover sites of early human activity without structures and the remains of vehicles, vessels and aircraft;
- "heritage open spaces" incorporating existing registered parks and gardens and registered battlefields;

- World Heritage Sites and

- Marine heritage sites.

Assets are to be included on the Registers for their "special historic, archaeological, architectural or artistic interest". (It will be noted that conservation areas are not included in the Register.)

Once included on the Register, heritage asset consent ("HAC") would be required for demolition, damage or destruction, works for the purpose of removing or repairing or making any alteration or addition or any flooding or tipping alterations affecting the special interest of a heritage structure (but not for a heritage open space). All HAC applications would be dealt with by the local planning authority ("LPA"). (As an aside, many, if not most, LPAs do not have the expertise to deal with applications relating to what we currently call scheduled monuments and it is not clear that they will be resourced to acquire the necessary expert staff.)

The other "big idea" espoused in the Bill is heritage partnership agreements whereby owners of large or complex sites will be able, as an alternative to obtaining historic asset consent for each item of works they propose, to enter into an agreement with the local planning authority (and, if required, English Heritage) agreeing a programme of works over a period of years. Inevitably this would involve a lot of "front end" work and consultation, and I seriously query how much uptake there is likely to be.

Overall, what the Bill does is stitch together the existing listing and scheduling systems. (The numbers of parks, gardens, battlefields and world heritage sites are very small and therefore they are rarely encountered in practice). From a planning practitioner's point of view, therefore, it is difficult to see how the proposed system will be significantly different to the existing situation.

\footnotetext{
Nigel Hewitson

Head of Planning at Norton Rose LLP, and a former Legal Director of English Heritage

This article is a shorter version of an article which appeared in the July edition of the Journal of Planning and Environment Law and is based on a paper presented by the author to the IALS on 23rd January 2008.
} 